\title{
Impact of crisis resource management simulation-based training for inter professional and interdisciplinary teams: a systematic review
}

Lillia Fung, Sylvain Boet, M. Dylan Bould, Haytham Qosa, Laure Perrier, Andrea Tricco, Walter Tavares, and Scott Reeves

Version Post-print/accepted manuscript

Citation Fung L, Boet S, Bould MD, Qosa H, Perrier L, Tricco AC, Tavares W, (published version) Reeves $\mathrm{S}$. Impact of crisis resource management stimulation-based training for interprofessional and interdisciplinary teams: A systematic review. J Interprof Care. 2015 Aug 28;29(5):433-44.

Publisher's Statement This is an Accepted Manuscript of an article published by Taylor \& Francis in Journal of Interprofessional Care on 5-14-2015, available online: http://www.tandfonline.com/10.3109/13561820.2015.1017555.

How to cite TSpace items

Always cite the published version, so the author(s) will receive recognition through services that track citation counts, e.g. Scopus. If you need to cite the page number of the author manuscript from TSpace because you cannot access the published version, then cite the TSpace version in addition to the published version using the permanent URI (handle) found on the record page.

This article was made openly accessible by $U$ of $T$ Faculty.

Please tell us how this access benefits you. Your story matters. 


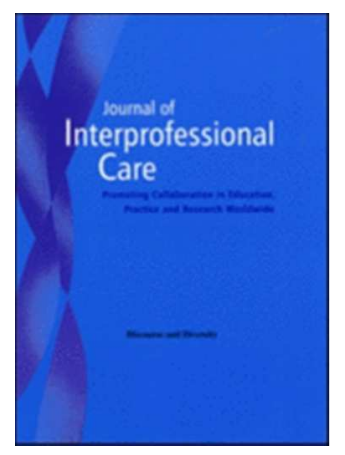

Impact of crisis resource management simulation-based training for interprofessional and interdisciplinary teams: a systematic review

\begin{tabular}{|r|l|}
\hline Journal: & Journal of Interprofessional Care \\
\hline Manuscript ID: & CJIC-2014-0432.R1 \\
\hline Manuscript Type: & Article \\
\hline Keywords: & $\begin{array}{l}\text { Crisis resource management, Interprofessional , Interdisciplinary, } \\
\text { Simulation-based training, Systematic review }\end{array}$ \\
\hline
\end{tabular}

\section{SCHOLARONE"}

Manuscripts 


\title{
Impact of crisis resource management simulation-based training for interprofessional and interdisciplinary teams: a systematic review
}

\begin{abstract}
Crisis resource management (CRM) abilities are important for different health care providers to effectively manage critical clinical events. This study aims to review the effectiveness of simulation-based CRM training for interprofessional and interdisciplinary teams compared to other instructional methods (e.g. didactics). Interprofessional teams are composed by several professions (e.g. nurse, physician, midwife) while interdisciplinary teams are composed by several disciplines from the same profession (e.g. cardiologist, anesthesiologist, orthopaedist). Medline, EMBASE, CINAHL, Cochrane Central Register of Controlled Trials, and ERIC were searched using terms related to CRM, crisis management, crew resource management, teamwork, and simulation. Trials comparing simulation-based CRM team training versus any other methods of education were included. The educational interventions involved interprofessional or interdisciplinary healthcare teams. The initial search identified 7,456 publications, 12 studies were included. Simulation-based CRM team training was associated with significant improvements in CRM skill acquisition in all but two studies when compared to didactic case-based CRM training or simulation without CRM training. Of the 12 included studies, one showed significant improvements in team behaviours in the workplace, while two studies demonstrated sustained reductions in adverse patient outcomes after a single simulation-based CRM team intervention. In conclusion, CRM simulation-based training for interprofessional and interdisciplinary teams shows promise in teaching CRM in the simulator when compared to didactic case-based CRM education or simulation without CRM teaching.
\end{abstract}


More research however is required to demonstrate transfer of learning to workplaces and potential impact on patient outcomes.

\section{Introduction}

In 1999, the Institute of Medicine (IOM) estimated that 100,000 annual deaths were attributed to clinical errors in the United States (Kohn, Corrigan, \& Donaldson, 2000). The most common sources of errors were not from failures of clinical knowledge or skill, but rather deficiencies with communication, coordination and teamwork (Reeves, Lewin, Espin, \& Zwarenstein, 2010; Williamson, Webb, Sellen, Runciman, \& Van der Walt, 1993). According to the IOM the majority of clinical errors were not the result of individual actions, but rather a failure of teams, systems or processes. This led to a call to: train in teams those who are expected to work in teams (Kohn et al., 2000).

While all communication, coordination and teamwork abilities are relevant in routine elective patient care, they are particularly important for crisis resource management (CRM) situations, i.e. life-threatening emergencies, for which urgent and coordinated actions between different disciplines and professions are needed to ensure safe patient care. CRM includes clinical as well as communication and teamworking abilities, however for the purposes of this paper we will focus only on the communication and coordination abilities which have been shown to be essential for the delivery of collaborative care (Cheng, Donoghue, Gilfoyle, \& Eppich, 2012; Gaba, Howard, Fish, Smith, \& Sowb, 2001). Therefore, in this paper when we use the phrase "CRM" we refer to principles such as leadership and followership, communication, teamwork, resource use, and situational awareness (Cheng et al., 2012). The abilities that are 
required for effective CRM are often dependent on effective interprofessional practice (Willems, Waxman, Bacon, Smith, \& Kitto, 2013).

\section{Background}

In 2010, a large North American study demonstrated that an interprofessional training program for operating room teams (surgeons, anesthesiologists, nurses, and technicians) was associated with a lower surgical mortality (Neily et al., 2010). While interest in team-based training continues to grow (Buljac-Samardzic, Dekker-van Doorn, van Wijngaarden, \& van Wijk, 2010; Salas et al., 2008; Weaver et al., 2010), the best method of delivering training has yet to be determined (Cheng et al., 2012; Ostergaard, Dieckmann, \& Lippert, 2011). Gaba and colleagues (2001) promoted simulation as the ideal setting to teach and practice team based CRM skills. Simulation has not only been shown to be an effective tool for teaching new knowledge, skills, and behaviours compared to no intervention (Cook et al., 2011), but a recent review concluded that simulation was more effective than traditional clinical education approaches (e.g., "see one, do one, teach one" approach) at achieving specific skill acquisition goals (McGaghie, Issenberg, Cohen, Barsuk, \& Wayne, 2011). Simulation not only brings together members from various professions (interprofessional, e.g. nurse, physician, midwife) or disciplines (interdisciplinary, e.g. cardiologist, anesthesiologist, orthopaedist), but it allows teams to practice the management of high-stakes clinical emergencies in an environment uncoupled from adverse events.

Reviews exploring the use of simulation to teach CRM, however, are limited. For instance, one previous review (Doumouras, Keshet, Nathens, Ahmed, \& Hicks, 2012) demonstrated 
positive participant feedback and changes in team behaviours in the simulator, but provided limited evidence related to transfer of learning to the workplace or patient benefits. This earlier review also had significant limitations: the studies included were limited to medical residents, and only three out of 15 included studies were of interdisciplinary teams, interprofessional teams were not included (Doumouras et al., 2012).

This paper reports the findings from a systematic review aimed to assess: (i) the effectiveness of simulation-based CRM team training compared to any other educational intervention among interprofessional or interdisciplinary teams, and (ii) determine whether simulation-based CRM team training leads to the modification of attitudes, skill/knowledge acquisition, changes in behaviours, and improved patient outcomes.

\section{Methods}

The Preferred Reporting Items for Systematic Reviews and Meta-Analyses (PRISMA) Statement was used to guide the reporting of this review (Moher, Liberati, Tetzlaff, \& Altman, 2010).

Protocol

A review protocol was compiled and revised by the authors including researchers (AT, LP, SR), educators ( $S B, M D B)$, and clinicians ( $S B, M D B, W T, H Q, L F)$. This is available from the corresponding author upon request.

Eligibility criteria 
Experimental (randomized controlled trials [RCT], quasi-randomized controlled trials [method of allocating participants to treatment not strictly random]) and quasi-experimental designs (controlled before-after studies [CBA] and interrupted time series [ITS]) were eligible for inclusion. Eligible participants included all healthcare providers (e.g., physicians, nurses, emergency response team personnel, respiratory therapists, paramedics, midwives). All levels of training were included (pre- and post-registration, undergraduate, postgraduate, and staff). Studies comparing simulation-based education versus any other method of education were eligible for inclusion. The education intervention included CRM in emergency or high-stakes situations involving a team (at least two individuals from different disciplines/professions). Single learner interventions were excluded. Team training encompassed both interprofessional or interdisciplinary education. The former was defined as two or more professions (e.g., a nurse and a physician) who learn with, from, and about each other, to improve collaboration, the quality of care or both (EPOC, 2014). The latter was defined as any team of health practitioners from the same profession but from two or more clinical specialties (e.g., two physicians, one nephrologist and another cardiologist). Interventions that did not explicitly mention the terms "CRM" or "crew resource management" as interventions, but taught communication and team coordination abilities during a clinical crisis were also included. Studies were only considered for inclusion if they were published in a language understood by the study team (English or French).

[INSERT BOX 1 HERE]

The primary outcome collected was CRM learning acquired. Learning was categorized based on the Kirkpatrick model of educational outcomes, as modified by Phillips (1997) (Table 1). The 
original classification described by Kirkpatrick was divided into 4 levels, with level 4 (highest) being "patient outcome". Phillips added a fifth level to include return on investment of education programs (Phillips, 1997). Outcomes with Kirkpatrick levels of 2 or greater were included. Studies with only Kirkpatrick level 1 outcomes were excluded because they measured learners' reactions, rather than objective measures of learning. Furthermore, studies with outcomes that relied solely on self-assessed data were excluded because self-assessments conducted by health care workers may be unreliable and inaccurate (Davis et al., 2006; Eva \& Regehr, 2005). The only exception was data on modification of attitudes/behaviours (Kirkpatrick 2a) where self-reflection was the only means of collecting this information. [INSERT TABLE 1 HERE]

\section{Data Sources}

A librarian (LP) searched the electronic databases including Medline, EMBASE, CINAHL, Cochrane Central Register of Controlled Trials, and ERIC on September $4^{\text {th }}, 2012$. There were no restrictions on publication year. For each database, the following search terms were used: crisis resource management, crisis management, crew resource management, teamwork, and simulation.

\section{Study Selection}

The titles and abstracts of identified citations were divided among paired authors who independently screened the citations for compliance with the eligibility criteria (SB, WT, ACT, LP, HQ and LF). Disagreements about eligibility were recorded and resolved by consensus. Two 
authors (HQ and LF) independently screened the full text articles for eligibility. Disagreements about eligibility were recorded and resolved by consensus or the involvement of another team member (SB, MDB or SR).

\title{
Data items and abstraction
}

The following information was extracted from each article: study design, sample size, characteristics of the study population, context of the study environment, description of the learning intervention, nature of the comparison group, and data on the primary outcomes, as mentioned above. Where data was inadequately reported within the full text article, attempts were made by email to contact the original authors of the article for clarification and further details. Data abstraction was not blinded (Moher, Horsley, Morgan, Tricco, \& Tsertsvadze, 2011) and was performed by two team members, independently (LF and HQ).

\author{
Risk of bias appraisal \\ Risk of bias was assessed using the Review Group of Cochrane Collaboration's Effective Practice \\ and Organisation of Care Group tool (EPOC, 2014) by two team members, independently (LF \\ and $\mathrm{HQ})$.
}

\section{Synthesis}

Data were not pooled for meta-analysis because of the high degree of heterogeneity in included studies; therefore, a narrative description was conducted. 


\section{Results}

The literature search strategy identified 7456 citations (Figure 1), of which 443 were eligible for the full text review. Fifteen articles met our inclusion criteria, which represented 12 independent studies (Boet et al., 2013; Crofts et al., 2008; Crofts et al., 2007; Daniels et al., 2010; Ellis et al., 2008; Frengley et al., 2011; Jankouskas, Haidet, Hupcey, Kolanowski, \& Murray, 2011; LeFlore \& Anderson, 2009; Miller, Crandall, Washington, \& McLaughlin, 2012; Phipps et al., 2012; Riley et al., 2011; Shapiro et al., 2004; Siassakos, Draycott, Montague, \& Harris, 2009; Thomas et al., 2007; Thomas et al., 2010). Four of the articles included in the review were companion reports from the UK SaFE trial and, together were considered one independent study (Crofts et al., 2008; Crofts et al., 2007; Ellis et al., 2008; Siassakos et al., 2009).

\section{[INSERT FIGURE 1 HERE]}

\section{Study and patient characteristics}

Included articles were published between 2004 and 2013. Ten of the included articles were RCTs, (Boet et al., 2013; Crofts et al., 2008; Crofts et al., 2007; Daniels et al., 2010; Ellis et al., 2008; Frengley et al., 2011; Jankouskas et al., 2011; LeFlore \& Anderson, 2009; Riley et al., 2011; Shapiro et al., 2004; Siassakos et al., 2009; Thomas et al., 2007; Thomas et al., 2010) and two were ITS studies (Miller et al., 2012; Phipps et al., 2012). Approximately 1,099 participants or 202 teams were included in the review. Total counts for participant and team numbers were approximated due to the inconsistent reporting among studies; some studies either failed to mention the number of teams (Phipps et al., 2012; Riley et al., 2011), study participants (Miller et al., 2012) or provided ranges of the number of participants on each team (Thomas et al., 
2007; Thomas et al., 2010). Comparator groups used to assess learning effectiveness varied among studies, but clustered naturally into three types: studies comparing simulation-based CRM versus didactic or case-based CRM team training (Table 2); studies comparing simulationbased CRM team training versus simulation without CRM teaching, where simulation scenarios were identical, but teaching objectives in the experimental group included both CRM instruction, while the control groups only received procedural teaching (e.g. shoulder dystocia) (Table 3); and lastly, a miscellaneous group including studies comparing a specific simulationbased teaching method or learning outcomes assessed using an ITS study design (Table 4).

\section{[INSERT TABLE 2, 3 \& 4 HERE]}

\section{Team profiles}

Five studies involved interprofessional teams (Crofts et al., 2008; Crofts et al., 2007; Daniels et al., 2010; Ellis et al., 2008; Frengley et al., 2011; Jankouskas et al., 2011; Shapiro et al., 2004; Siassakos et al., 2009), and five were both interprofessional and interdisciplinary (Boet et al., 2013; LeFlore \& Anderson, 2009; Miller et al., 2012; Phipps et al., 2012; Riley et al., 2011), while two only involved interdisciplinary teams (Thomas et al., 2007; Thomas et al., 2010). Physicians and nursing were the most common professions, represented in 12 and nine studies, respectively. Midwives (Crofts et al., 2008; Crofts et al., 2007; Ellis et al., 2008; Phipps et al., 2012), certified registered nurse anesthetists, physician assistants (Phipps et al., 2012; Riley et al., 2011), social workers and respiratory therapists (LeFlore \& Anderson, 2009) were included in six studies. One study (Miller et al., 2012) mentioned technicians, pharmacists, clerks, and respiratory therapists, but how many and the extent of their involvement was unclear. Lastly, 
three studies (Boet et al., 2013; Daniels et al., 2010; LeFlore \& Anderson, 2009) reported prior simulation exposure among $15 \%$ to $54 \%$ of participants.

\section{Context of the simulated crisis}

Crisis scenarios used to teach CRM principles were divided into three themes: acute/critical care event (Boet et al., 2013; Frengley et al., 2011; Jankouskas et al., 2011; Miller et al., 2012; Shapiro et al., 2004), obstetric emergencies (Crofts et al., 2008; Crofts et al., 2007; Daniels et al., 2010; Ellis et al., 2008; Phipps et al., 2012; Riley et al., 2011; Siassakos et al., 2009), and neonatal resuscitation (LeFlore \& Anderson, 2009; Thomas et al., 2007; Thomas et al., 2010). Examples of acute/critical care event include trauma activations (Miller et al., 2012), cardiac arrhythmias in the operating room (Boet et al., 2013), airway emergencies (Frengley et al., 2011), and basic life support (Jankouskas et al., 2011). Emergencies involving obstetric teams involved post-partum haemorrhage (Siassakos et al., 2009); eclampsia (Daniels et al., 2010; Ellis et al., 2008); uterine rupture and placental abruption (Riley et al., 2011); and dystocia (Daniels et al., 2010).

\section{Simulation characteristics}

High-fidelity, computer-controlled mannequin simulators in a simulation lab were the most common simulator platform used by seven studies (Boet et al., 2013; Crofts et al., 2008; Crofts et al., 2007; Daniels et al., 2010; Ellis et al., 2008; Frengley et al., 2011; Jankouskas et al., 2011; Shapiro et al., 2004; Thomas et al., 2010). Another four studies used in-situ simulators, where simulation trials took place in real work-place settings: three involved standardized patients 
(Phipps et al., 2012; Riley et al., 2011; Siassakos et al., 2009) and one with high-fidelity, computer-controlled mannequins in a real emergency department (Miller et al., 2012). Only one study used a low-fidelity simulated baby as the sole simulation intervention (Thomas et al., 2007). Two studies evaluated outcomes comparing simulation modalities with varied results; for example, Thomas and colleagues (2010) demonstrated better scores on validated team behaviour measurements with high-fidelity compared to low-fidelity simulators, meanwhile papers in the UK SaFE study showed either no difference (Ellis et al., 2008) or better outcomes in patient-actor perceived scores for team safety and communication in the low-fidelity groups, using patient-actors and basic mannequins, compared to the high-fidelity groups in a dedicated simulation centre (Crofts et al., 2008).

\section{Learning intervention}

CRM was only explicitly described in seven studies (Boet et al., 2013; Crofts et al., 2008; Crofts et al., 2007; Daniels et al., 2010; Ellis et al., 2008; Jankouskas et al., 2011; LeFlore \& Anderson, 2009; Phipps et al., 2012; Shapiro et al., 2004; Siassakos et al., 2009). Remaining studies described "teamwork and human error" (Thomas et al., 2007; Thomas et al., 2010), "teamwork and communication" (Miller et al., 2012), "human factors and crisis management" (Frengley et al., 2011), or employed TeamSTEPPS ${ }^{\circledR}$, an evidence-based teamwork curriculum focused on leadership, situation monitoring, mutual support, and communication (Riley et al., 2011). Length of didactic CRM teaching ranged from brief (<30 $\mathrm{min}$ ) (Boet et al., 2013; LeFlore \& Anderson, 2009), to lasting hours (2-4 hours) (Phipps et al., 2012; Thomas et al., 2007; Thomas et al., 2010), one day (Crofts et al., 2008; Crofts et al., 2007; Ellis et al., 2008; Siassakos et al., 
2009) or were unspecified (Frengley et al., 2011; Jankouskas et al., 2011). Some studies also included additional reading material (Crofts et al., 2008; Crofts et al., 2007; Ellis et al., 2008; Siassakos et al., 2009), videos (Shapiro et al., 2004; Thomas et al., 2007) or webinars (Riley et al., 2011). Evaluation of the effect of didactic CRM presentations on the simulation experience took place immediately after the presentation, except in two studies where the simulation took place $3-5$ days (Phipps et al., 2012) or up to 8 weeks later (Miller et al., 2012).

Debriefing was involved in all studies, but instructor expertise, duration, and methods varied. Instructors underwent simulation and teamwork training programs in three studies (Crofts et al., 2008; Crofts et al., 2007; Ellis et al., 2008; Phipps et al., 2012; Thomas et al., 2007), while seven studies used "expert" simulation and or CRM training instructors (Jankouskas et al., 2011; LeFlore \& Anderson, 2009; Miller et al., 2012; Shapiro et al., 2004; Thomas et al., 2010), some with up to 2-years of experience (Boet et al., 2013; Daniels et al., 2010). Instructor experience was not mentioned in two studies (Frengley et al., 2011; Riley et al., 2011). When reported, duration of feedback ranged from 15 minutes to 2 hours (Daniels et al., 2010; Miller et al., 2012; Riley et al., 2011). Video-assisted debriefing was included in six studies (Boet et al., 2013; Daniels et al., 2010; Jankouskas et al., 2011; LeFlore \& Anderson, 2009; Phipps et al., 2012; Shapiro et al., 2004). One study included "within team" debriefing among simulation participants without an instructor (Boet et al., 2013), while another had "instructor-modelled learning" where trainees complete a simulation scenario followed by an observed expert modeled learning simulation scenario and modified debriefing (LeFlore \& Anderson, 2009). 
Previously validated measurement tools were utilized in six studies at outcome levels ranging from Kirkpatrick 2 to 4, which are detailed in Tables 2-4.

\section{Learning outcomes}

The 12 included studies reported the following range of outcomes:

\section{Modification of attitudes and perception (Kirkpatrick 2a)}

Jankouskas and colleagues (2011) compared interprofessional attitudes between simulationbased CRM trained versus simulation without CRM training, but no differences were found ( $p$ value not reported). Pre- to post-intervention validated surveys assessing "culture of safety" attitudes among participants were described in two studies, but they also found no significant difference from baseline when composite scores were assessed (both $p>0.05$ ) (Phipps et al., 2012; Riley et al., 2011). In one of the two studies, however, a sub-analysis was preformed and domains specific to labour and delivery CRM dimensions demonstrated improvements in teamwork, communication, and non-punitive responses to error $(p<0.01)$ (Phipps et al., 2012). Lastly, qualitative responses from an unvalidated follow-up survey by Frengley and colleagues (2011) remarked that participants retained what they learned, involved the team more, and even made changes to patient management.

\section{CRM Skills acquired in the simulator (Kirkpatrick 2b)}

Studies comparing simulation-based to didactic or case-based CRM team training (Table 2) showed improved teamwork behaviours in a post-test simulator scenario $(p<0.01)$ (Frengley et 
al., 2011), team efficacy, and overall teamwork with simulation-based teaching $(p<0.03)$

(Daniels et al., 2010). Studies comparing simulation-based CRM team training to simulation training without CRM teaching (Table 3) also showed better performance for CRM abilities ("anaesthetists' non-technical skills" score - ANTS; p<0.05) (Jankouskas et al., 2011); more team behaviours, vigilance, better workload management (no p-value reported (Thomas et al., 2007) and $p<0.01$ (Thomas et al., 2010)); and more "directed" comments (descriptive analysis only) (Siassakos et al., 2009). In contrast, while the UK SaFE study (Crofts et al., 2008; Ellis et al., 2008) showed improved communication, safety, and overall teamwork skills from pre- to posttest scores $(p<0.01)$, teamwork theory did not show any added benefit when compared to simulation training alone ( $p>0.37)$. Lastly, two studies compared teaching methods for simulation-based CRM team training on specific communication and coordination abilities in the simulator (Boet et al., 2013; LeFlore \& Anderson, 2009). Boet and colleagues (2013) demonstrated that simulation-based CRM teaching was effective in improving healthcare team CRM performance in the simulator, when team debriefing was facilitated with or without an instructor $(p=0.01)$. There was no significant difference in the degree of effectiveness between the two types of team debriefings ( $p=0.52)$. In contrast, while LeFlore and Anderson (2009) had an instructor debriefing in both experiential groups, their modification on the initial simulation teaching method resulted in significant differences in CRM skill acquisition. They showed that instructor learning with modified debriefing was more effective in teaching CRM skills than selfdirected learning with an instructor debriefing during team-simulated clinical scenarios $(p<0.04)$. 
Knowledge or skills in the simulator (Kirkpatrick $2 b$ )

Simulation-based CRM team training did not reveal additional benefit on error rates and response times $(p=0.43$ ) (Jankouskas et al., 2011), the completion of basic tasks $(p>0.05)$ (Ellis et al., 2008) or multiple choice scores ( $p>0.97$ )(Crofts et al., 2007) when compared to simulation teaching without CRM training. Only one study (Thomas et al., 2010) found that teams who received additional teamwork training showed improved workload management $(p<0.01)$ and completed resuscitations an average of 2.6 minutes faster than teams that did not receive additional teamwork training. When simulation-based team training was compared to didactic CRM training alone, multiple-choice scores were not different ( $p>0.05)$ (Daniels et al., 2010). In the study by LeFlore and Anderson (2009) where different simulation-based teaching styles were compared, teams with "instructor-modelled learning" had significantly better scores in eight out of 11 items on the evaluation tool compared to teams trained using "self-directed learning."

Behaviour change in the workplace (Kirkpatrick 3)

Two studies used trained assessors to observe outcomes during real team traumas after learning CRM in the simulator. Shapiro and colleagues (2004) found no statistical difference in pre- and post-intervention behaviours in the workplace when they compared simulation-based CRM team training program $(p=0.07)$ and didactic-based CRM teaching $(p=0.55)$. Meanwhile, Miller and colleagues (2012) showed that teams during the didactic phase of the CRM intervention only improved on one out of 14 teamwork domains $(p=0.05)$ in a real emergency department setting, while 11 out of 14 domains $(p<0.04)$ improved during the simulation phase. 
All measures, however, returned to baseline during their "decay" phase 1 week following the simulation phase $(p>0.41)$.

\section{Benefits to patients (Kirkpatrick 4)}

Riley and colleagues (2011) demonstrated that a hospital-wide teaching simulation-based CRM team intervention reduced mean weighted adverse outcomes scores (WAOS) compared to hospitals randomized to didactic CRM teaching only or no teaching at all $(p<0.05)$. This effect was seen as early as one quartile after the intervention and sustained for the 2-year study period. Likewise, Phipps and colleagues (2012) showed a reduction in adverse outcome index (AOI) from $0.052(95 \% \mathrm{Cl}, 0.05-0.05)$ to $0.04(95 \% \mathrm{Cl}, 0.04-0.05)$ in perinatal outcomes over 6 quarters (1.5 years) following a simulation-based CRM team training course. Both the WAOS and $\mathrm{AOI}$ were based on 10 quality indicators: maternal death, intrapartum neonatal death, uterine rupture, unplanned transfer to the intensive care unit, birth trauma, admission to the neonatal intensive care unit, Apgar score at 5 minutes $<7$, return to the operating room, thirdfourth degree perineal laceration, or the need for a blood transfusion

Return on investment (Kirkpatrick 5)

No studies showed outcomes describing return on investment of team simulation-based CRM training.

Retention 
Included studies investigated retention of skills across the Kirkpatrick levels, but their outcomes were variable. For example, retention of team behaviours in simulated environments were seen up to 6 months post-intervention (Kirkpatrick 2b) (Thomas et al., 2010). Miller and colleagues (2012), however, found that CRM skills in the workplace (Kirkpatrick 3) returned to baseline only after 1 week. This may be due to a treatment effect as only $25 \%$ of the potential trauma team underwent the in-situ trauma simulation intervention. Meanwhile, two studies investigating outcomes at the level of patient benefits (Kirkpatrick 4), showed that benefits were maintained from 18 months to 2 years after a single team CRM simulation intervention (Phipps et al., 2012; Riley et al., 2011).

\section{Risk of bias}

The EPOC tool was used to appraise bias among included studies (Appendix) (EPOC, 2014). Random sequence generation was unclear in four studies (Frengley et al., 2011; LeFlore \& Anderson, 2009; Shapiro et al., 2004; Siassakos et al., 2009). Allocation concealment was not mentioned in any of the RCTs. Baseline outcomes were incomplete (Daniels et al., 2010; Jankouskas et al., 2011; LeFlore \& Anderson, 2009), non-existent (Thomas et al., 2007; Thomas et al., 2010) or were dissimilar (Siassakos et al., 2009) in five studies. Five studies failed to disclose baseline participant characteristics (Crofts et al., 2008; Crofts et al., 2007; Ellis et al., 2008; Frengley et al., 2011; Shapiro et al., 2004; Siassakos et al., 2009; Thomas et al., 2007; Thomas et al., 2010); one had notable differences, where the didactic group had almost twice as many deliveries per year, with a non-proportional increase in nurses and more family physicians (Riley et al., 2011). Three studies suffered from significant dropouts (Daniels et al., 
2010; Frengley et al., 2011; Phipps et al., 2012) or an uneven loss of data in one arm due to audio-visual issues (Thomas et al., 2010). Three studies were also unable to blind live assessors to the allocation of pre- versus post-intervention (Crofts et al., 2008; Miller et al., 2012; Shapiro et al., 2004), while another used an unblinded principal investigator as the simulator instructor (Jankouskas et al., 2011). Contamination bias, which occurs when members of the control group are inadvertently exposed to the learning intervention ("Cochrane Handbook for Systematic Reviews of Interventions Version 5.0.1," 2008) was at risk in two studies, one where both groups were exposed to the intervention - high-fidelity CRM - albeit in different clinical settings (Frengley et al., 2011) and another where changes in institutional policies or personnel during the study period may have contributed to contamination (Riley et al., 2011). Other biases noted included self-selection bias among volunteer participants (Daniels et al., 2010; Jankouskas et al., 2011), responder bias (Frengley et al., 2011), selection bias (Thomas et al., 2010), and sampling bias (Miller et al., 2012). Studies comparing simulation-based CRM teaching to simulation without CRM teaching (Table 3) controlled for potential contamination by separating the groups during their simulation intervention. Lastly, among the two ITS studies (Miller et al., 2012; Phipps et al., 2012), it was unclear if the intervention was independent of other changes, both studies did not comment on possible confounders or historical events during the experimental period that may have influenced outcomes. 


\section{Discussion}

This review aimed to assess the effectiveness of interprofessional and interdisciplinary simulation-based CRM team training compared to any other education intervention. All but one of the included interprofessional and interdisciplinary studies found significant improvements in at least one of the learning outcomes when using simulation-based CRM team training compared to alternate forms of training, such as didactic teaching or case-based learning. The only interprofessional study that did not show any difference in learning outcome had a very small sample size $(n=4)$ (Shapiro et al., 2004) which resulted in a lack of statistical power. No studies reported outcomes that were worse in the simulation-based CRM training group compared to any comparator group. We conclude that CRM simulation-based training for interprofessional and interdisciplinary teams shows promise as a superior training method over traditional non-simulation clinical teaching of CRM principals.

Despite correlations between clinical and team coordination abilities for individual CRM simulation training (Riem, Boet, Bould, Tavares, \& Naik, 2012), this review found limited evidence to support the benefit of additional team-based simulation CRM teaching on enhancing clinical knowledge or skills. Clinical performance improved for pre- to postintervention scores, but teams that received additional instruction on CRM teaching (Crofts et al., 2007; Ellis et al., 2008; Jankouskas et al., 2011), or added simulation to an existing didacticbased CRM intervention (Daniels et al., 2010), fared no better than those that did not. Only one study showed improved team clinical knowledge or skills with additional team training (Thomas et al., 2010). One possibility was that clinical knowledge or skill development was a general 
effect of rehearsal and CRM teaching posed no additional benefit to learning. Simulation-based CRM team training, however, showed significant and reproducible improvements in CRM communication and team coordination abilities, (Daniels et al., 2010; Frengley et al., 2011; Jankouskas et al., 2011; Siassakos et al., 2009; Thomas et al., 2007; Thomas et al., 2010) which suggests the benefits seen in patient outcomes found in other studies (Phipps et al., 2012; Riley et al., 2011) were a function of specific communication and TEAM coordination abilities for CRM learned rather than clinical knowledge or skills, but more evidence is needed to affirm this.

The retention of CRM skills across the Kirkpatrick levels was inconsistent and remains unclear. Retention of CRM skills was seen up to 6 months in a simulated environment (Thomas et al., 2010), which was consistent with previous work published on non-team based interventions (Naik, Savoldelli, Joo, Chandra, \& Weiss, 2007). At higher levels of learning, however, retention of CRM skills were only seen for up to one week when measured in the workplace (Miller et al., 2012). Possible reasons for this includes study design, other confounding variables affecting retention in real-life settings, or more simulation-based training may be needed for skill retention in the workplace compared to the simulator. This was further complicated by other studies that showed retention at even higher Kirkpatrick levels, (i.e., patient benefits), that lasted as long as 18 to 24 months after a single simulation-based CRM team training intervention. Possible confounders were not assessed in these studies. Therefore, it is also unclear why a simulation-based team intervention might improve patient outcomes longer than 
measurable workplace performances in CRM reported in other studies and warrants further investigation.

We acknowledge the importance of debriefing in simulation-based training (Fanning \& Gaba, 2007); however, studies need to be done to consolidate the various methods that exist and consider cost-effectiveness. While one study showed that the presence of an expert debriefer was not systematically necessary to achieve measured CRM learning in teams in the simulator (Boet et al., 2013), another showed that more instructor-led interventions in the form of instructor-modelled learning was better (LeFlore \& Anderson, 2009). Thus, there is a clear need for return on investment analysis (J. Phillips, 1995) to balance the facility and faculty costs of simulation-based training with teaching or health outcomes. This analysis should go further than asking if an intervention is effective or can be afforded in a budget. Rather it should ask whether the investment is worthwhile, after comparing the costs and outcomes together, between interventions (i.e., simulated team-based CRM training versus non simulated CRM team training or simulated individual CRM training)(Barton, Bryan, \& Robinson, 2004). This cost-effectiveness information is essential for decision-makers in order to promote the use of CRM simulation team training.

Several limitations should be considered. First, many of the included studies were limited by a high risk of bias. Second, incomplete descriptions of methods in the included publications limited our ability to fully describe the studies or make judgments on their methodological quality. Third, only English and French language studies were assessed. Fourth, our searches did 
not specifically include skills related team training/interprofessional training which may have resulted in missing papers that focused on these skills, unless they specifically mentioned the term CRM. As a result, studies may have been missed. Fifth, our finding might be affected by publication bias because unpublished studies were not included. Furthermore, some studies were limited by methodological shortcomings including small sample size (Shapiro et al., 2004), short follow-up time (Crofts et al., 2008; Daniels et al., 2010; Frengley et al., 2011; Shapiro et al., 2004; Siassakos et al., 2009; Thomas et al., 2007), and inadequate intervention exposure (Jankouskas et al., 2011; Riley et al., 2011). Lastly, we recognize there was significant heterogeneity in participation sample, study design, training intervention, and outcome analysis, which limited our ability to synthesize results.

\section{Concluding comments}

This review reports on 12 studies measuring learning outcomes after simulation-based CRM training for interprofessional and interdisciplinary teams of learners. Although positive outcomes were reported in all but two studies (Crofts et al., 2008; Ellis et al., 2008; Shapiro et al., 2004), generalizable conclusions cannot be reached due to the variety of learning interventions, methodologies, and outcome measurements. This review, however, demonstrates promise for the use of simulation-based CRM team training to enhance the acquisition of communication and coordination abilities for crises management, although there is still a need to align research practices and identify best practices. 
Future efforts should involve rigorous methodology, standardized learning interventions, and validated measurement tools. Areas of focus should emphasize knowledge translation into workplaces or effects on patients' outcome (Kirkpatrick 3 and 4) or study designs that elucidate the most effective and efficient means by which simulation-based CRM training is delivered (how often, and with whom). The latter should also involve a systematic analysis of return on investment, which may aid in increased accessibility to simulation training. Importantly, this review also highlights some challenges that prevail in CRM research. As noted by Salas and colleagues (2000), CRM suffers from 'definitional ambiguity' where no universal definition of CRM exists. Universal outcome measurements on the effectiveness of CRM interventions are also lacking. These limitations, along with heterogeneity in study design challenge the systematic assessment of studies. Given the present nature of simulation research, we acknowledge that definitive evidence will be difficult to achieve in support of team-based CRM training. Despite this, CRM simulation-based training for interprofessional and interdisciplinary teams continues to grow as a major player in multifaceted education programs aimed towards making health care teams work safer and more effectively.

\section{Acknowledgements}

The authors would like to thank Ashlee-Ann Pigford, Emily Hladkowicz, Sam Caldbick and Andrew Beck for critically reviewing the manuscript.

\section{Declaration of interest}

The authors report no declarations of interest. The authors were responsible for the writing and contents of this paper.

\section{References}


Barton, P., Bryan, S., \& Robinson, S. (2004). Modelling in the economic evaluation of health care: selecting the appropriate approach. Journal of Health Services Research \& Policy, 9(2), 110-118.

Boet, S., Bould, M. D., Sharma, B., Revees, S., Naik, V. N., Triby, E., \& Grantcharov, T. (2013). WithinTeam Debriefing Versus Instructor-Led Debriefing for Simulation-Based Education. Annals of Surgery, 258(1), 53-58. doi: 10.1097/SLA.0b013e31829659e4

Buljac-Samardzic, M., Dekker-van Doorn, C. M., van Wijngaarden, J. D., \& van Wijk, K. P. (2010). Interventions to improve team effectiveness: a systematic review. Health Policy, 94(3), 183-195. doi: 10.1016/j.healthpol.2009.09.015

Cheng, A., Donoghue, A., Gilfoyle, E., \& Eppich, W. (2012). Simulation-based crisis resource management training for pediatric critical care medicine: A review for instructors*. Pediatric Critical Care Medicine, 13(2), 197-203.

Cochrane Handbook for Systematic Reviews of Interventions Version 5.0.1. (2008). J. Higgins, Green, S (Ed.) Retrieved from http://www.cochrane-handbook.org.

Cook, D. A., Hatala, R., Brydges, R., Zendejas, B., Szostek, J. H., Wang, A. T., . . Hamstra, S. J. (2011). Technology-enhanced simulation for health professions education. JAMA, 306(9), 978-988.

Crofts, J. F., Bartlett, C., Ellis, D., Winter, C., Donald, F., Hunt, L. P., \& Draycott, T. J. (2008). Patient-actor perception of care: a comparison of obstetric emergency training using manikins and patientactors. Quality and Safety in Health Care, 17(1), 20-24. doi: 10.1136/qshc.2006.021873

Crofts, J. F., Ellis, D., Draycott, T. J., Winter, C., Hunt, L. P., \& Akande, V. A. (2007). Change in knowledge of midwives and obstetricians following obstetric emergency training: a randomised controlled trial of local hospital, simulation centre and teamwork training. BJOG: An International Journal of Obstetrics \& Gynaecology, 114(12), 1534-1541. doi: 10.1111/j.1471-0528.2007.01493.x

Daniels, K., Arafeh, J., Clark, A., Waller, S., Druzin, M., \& Chueh, J. (2010). Prospective Randomized Trial of Simulation Versus Didactic Teaching for Obstetrical Emergencies. Simulation in Healthcare, 5(1), 40-45. doi: 10.1097/SIH.0b013e3181b65f22

Davis, D. A., Mazmanian, P. E., Fordis, M., Van Harrison, R., Thorpe, K. E., \& Perrier, L. (2006). Accuracy of physician self-assessment compared with observed measures of competence. JAMA, 296(9), 1094-1102.

Doumouras, A. G., Keshet, I., Nathens, A. B., Ahmed, N., \& Hicks, C. M. (2012). A crisis of faith? A review of simulation in teaching team-based, crisis management skills to surgical trainees. Journal of Surgical Education, 69(3), 274-281.

EPOC - Effective Practice and Organisation of Care (2014). EPOC Resources for review authors. Retrieved from http://epocoslo.cochrane.org/epoc-specific-resources-review-authors

Ellis, D., Crofts, J. F., Hunt, L. P., Read, M., Fox, R., \& James, M. (2008). Hospital, simulation center, and teamwork training for eclampsia management: a randomized controlled trial. Obstet Gynecol, 111(3), 723-731. doi: 10.1097/AOG.0b013e3181637a82111/3/723 [pii]

Eva, K. W., \& Regehr, G. (2005). Self-assessment in the health professions: a reformulation and research agenda. Academic Medicine, 80(10), S46-S54.

Fanning, R. M., \& Gaba, D. M. (2007). The role of debriefing in simulation-based learning. Simulation in healthcare, 2(2), 115-125.

Frengley, R. W., Weller, J. M., Torrie, J., Dzendrowskyj, P., Yee, B., Paul, A. M., . . Henderson, K. M. (2011). The effect of a simulation-based training intervention on the performance of established critical care unit teams. Critical Care Medicine, 1. doi: 10.1097/CCM.0b013e3182282a98

Gaba, D. M., Howard, S. K., Fish, K. J., Smith, B. E., \& Sowb, Y. A. (2001). Simulation-based training in anesthesia crisis resource management (ACRM): a decade of experience. Simulation \& Gaming, 32(2), 175-193. 
Jankouskas, T. S., Haidet, K. K., Hupcey, J. E., Kolanowski, A., \& Murray, W. B. (2011). Targeted Crisis Resource Management Training Improves Performance Among Randomized Nursing and Medical Students. Simulation in Healthcare, 6(6), 316-326. doi: 10.1097/SIH.0b013e31822bc676

Kohn, L. T., Corrigan, J. M., \& Donaldson, M. S. (2000). To err is human: building a safer health system (Vol. 627): National Academies Press.

LeFlore, J. L., \& Anderson, M. (2009). Alternative educational models for interdisciplinary student teams. Simulation in Healthcare, 4(3), 135-142.

McGaghie, W. C., Issenberg, S. B., Cohen, M. E. R., Barsuk, J. H., \& Wayne, D. B. (2011). Does simulationbased medical education with deliberate practice yield better results than traditional clinical education? A meta-analytic comparative review of the evidence. Academic medicine: journal of the Association of American Medical Colleges, 86(6), 706.

Miller, D., Crandall, C., Washington, C., \& McLaughlin, S. (2012). Improving Teamwork and Communication in Trauma Care Through In Situ Simulations. Academic Emergency Medicine, 19(5), 608-612. doi: 10.1111/j.1553-2712.2012.01354.x

Moher, D., Horsley, T., Morgan, K., Tricco, A., \& Tsertsvadze, A. (2011). Blinded versus unblinded assessments of risk - of - bias in studies included in a systematic review. The Cochrane Library.

Moher, D., Liberati, A., Tetzlaff, J., \& Altman, D. G. (2010). Preferred reporting items for systematic reviews and meta-analyses: the PRISMA statement. International Journal of Surgery, 8(5), 336341.

Neily, J., Mills, P. D., Young-Xu, Y., Carney, B. T., West, P., Berger, D. H., . . Bagian, J. P. (2010). Association between implementation of a medical team training program and surgical mortality. Jama, 304(15), 1693-1700.

Ostergaard, D., Dieckmann, P., \& Lippert, A. (2011). Simulation and CRM. Best Pract Res Clin Anaesthesiol, 25(2), 239-249. doi: 10.1016/j.bpa.2011.02.003

Phillips, J. (1995). Return on Investment-Beyond the four levels. in: Academy of HRD.

Phillips, J. J. (1997). Handbook of training evaluation and measurement methods: Routledge.

Phipps, M. G., Lindquist, D. G., McConaughey, E., O'Brien, J. A., Raker, C. A., \& Paglia, M. J. (2012). Outcomes from a labor and delivery team training program with simulation component. American Journal of Obstetrics and Gynecology, 206(1), 3-9. doi: 10.1016/j.ajog.2011.06.046

Reeves, S., Lewin, S., Espin, S., \& Zwarenstein, M. (2010). Interprofessional Teamwork in Health and Social Care: Wiley-Blackwell.

Riem, N., Boet, S., Bould, M., Tavares, W., \& Naik, V. (2012). Do technical skills correlate with nontechnical skills in crisis resource management: a simulation study. British journal of anaesthesia, 109(5), 723-728.

Riley, W., Davis, S., Miller, K., Hansen, H., Sainfort, F., \& Sweet, R. (2011). Didactic and simulation nontechnical skills team training to improve perinatal patient outcomes in a community hospital. Joint Commission Journal on Quality and Patient Safety, 37(8), 357-364.

Salas, E., DiazGranados, D., Klein, C., Burke, C. S., Stagl, K. C., Goodwin, G. F., \& Halpin, S. M. (2008). Does team training improve team performance? A meta-analysis. Hum Factors, 50(6), 903-933.

Shapiro, M. J., Morey, J. C., Small, S. D., Langford, V., Kaylor, C. J., Jagminas, L., . . Jay, G. D. (2004). Simulation based teamwork training for emergency department staff: does it improve clinical team performance when added to an existing didactic teamwork curriculum? Quality and Safety in Health Care, 13(6), 417-421. doi: 10.1136/qshc.2003.005447

Siassakos, D., Draycott, T., Montague, I., \& Harris, M. (2009). Content analysis of team communication in an obstetric emergency scenario. Journal of Obstetrics \& Gynaecology, 29(6), 499-503. doi: $10.1080 / 01443610903039153$ 
Thomas, E. J., Taggart, B., Crandell, S., Lasky, R. E., Williams, A. L., Love, L. J., . . Helmreich, R. L. (2007). Teaching teamwork during the Neonatal Resuscitation Program: a randomized trial. Journal of Perinatology, 27(7), 409-414. doi: 10.1038/sj.jp.7211771

Thomas, E. J., Williams, A. L., Reichman, E. F., Lasky, R. E., Crandell, S., \& Taggart, W. R. (2010). Team Training in the Neonatal Resuscitation Program for Interns: Teamwork and Quality of Resuscitations. Pediatrics, 125(3), 539-546. doi: 10.1542/peds.2009-1635

Weaver, S. J., Lyons, R., DiazGranados, D., Rosen, M. A., Salas, E., Oglesby, J., . . King, H. B. (2010). The anatomy of health care team training and the state of practice: a critical review. Academic Medicine, 85(11), 1746-1760.

Willems, A., Waxman, B., Bacon, A. K., Smith, J., \& Kitto, S. (2013). Interprofessional non-technical skills for surgeons in disaster response: a literature review. Journal of interprofessional care, 27(5), 380-386.

Williamson, J., Webb, R., Sellen, A., Runciman, W., \& Van der Walt, J. (1993). The Australian Incident Monitoring Study. Human failure: an analysis of 2000 incident reports. Anaesthesia and intensive care, 21(5), 678-683.

INSERT APPENDIX HERE 
2

3

\section{Figure legends}

Figure 1. Search and selection of included studies

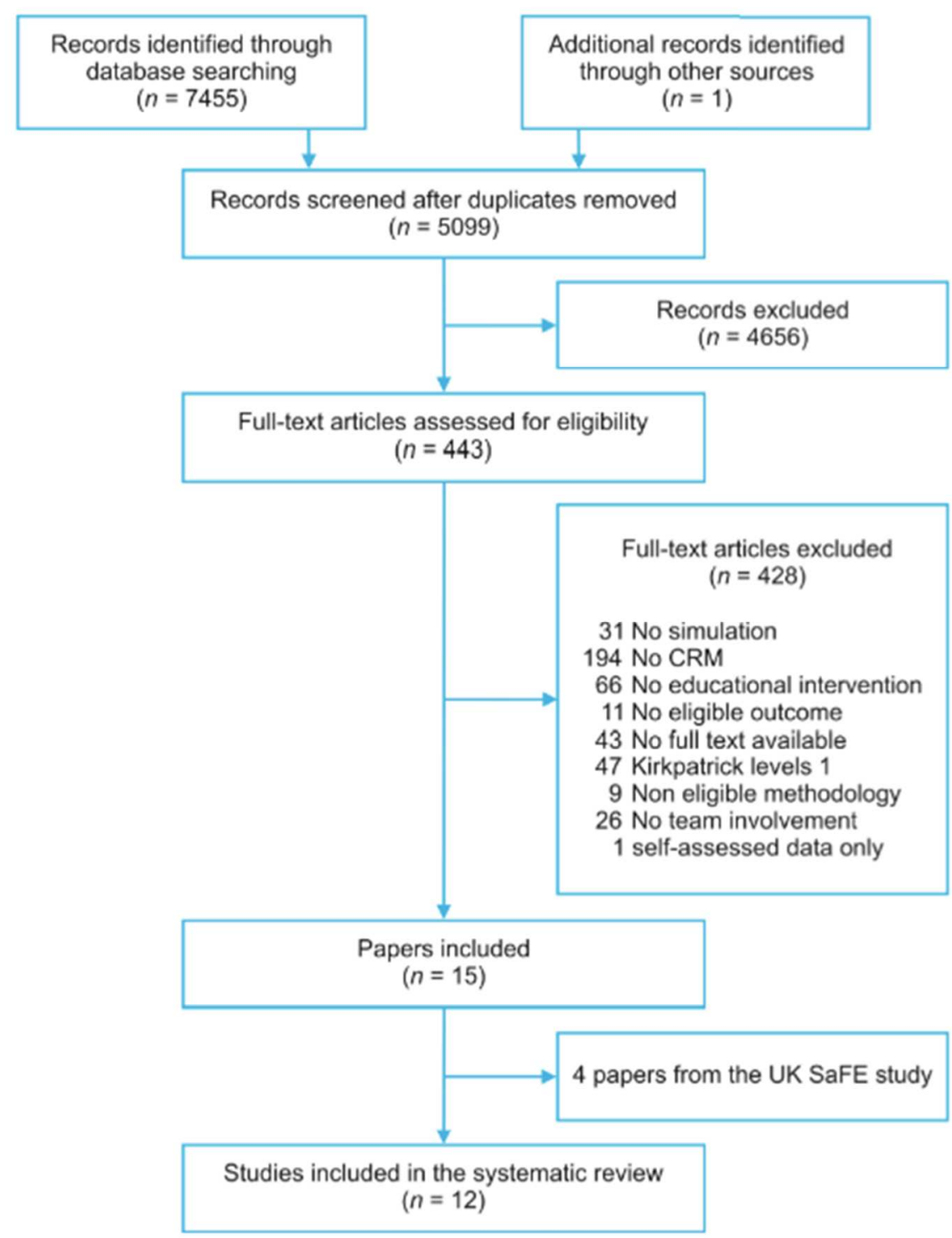

URL: http://mc.manuscriptcentral.com/cjic 
Box 1. Eligibility Criteria

Study characteristics

Randomized controlled trials or

Quasi-randomized controlled trials or

Controlled before-after studies or

Interrupted time series

Patient characteristics

All health care providers

All levels of training

Learning intervention

Inteprofessional or Interdisciplinary education

CRM

Simulation-based

URL: http://mc.manuscriptcentral.com/cjic 
Table 1. Classification of learning outcomes according to Kirkpatrick (modified by Phillips, 1997)

\begin{tabular}{|ll|}
\hline Level 1: Reaction & Participants view on the learning experience \\
\hline Level 2a: Modification of attitudes & Changes in attitudes towards team collaboration \\
\hline Level 2b: Acquisition of knowledge and skills & $\begin{array}{l}\text { Changes in CRM skill or knowledge or skill performance } \\
\text { in the simulator }\end{array}$ \\
\hline Level 3: Behavioral change & Transfer of CRM learning to the practice setting \\
\hline Level 4: Benefits to patients & Improvement in health or well being of patients \\
\hline $\begin{array}{l}\text { Level 5: Return on investment (Phillips, } \\
\text { 1995) }\end{array}$ & $\begin{array}{l}\text { Compares the training's monetary benefits with the } \\
\text { costs }\end{array}$ \\
\hline
\end{tabular}


Table 2. Studies comparing simulation-based crisis resource management verses didactic or casebased crisis resource management team training

\begin{tabular}{|c|c|c|c|c|c|}
\hline $\begin{array}{l}\text { Source, } \\
\text { Country }\end{array}$ & $\begin{array}{l}\text { Team, } \\
\text { participants }\end{array}$ & Study design & $\begin{array}{l}\text { Context of the } \\
\text { crisis, crisis } \\
\text { scenario(s) }\end{array}$ & $\begin{array}{l}\text { Learning } \\
\text { intervention }\end{array}$ & $\begin{array}{l}\text { Outcomes, } \\
\text { Kirkpatrick } \\
\text { level }\end{array}$ \\
\hline $\begin{array}{l}\text { Daniels et al., } \\
2010 \\
\text { USA }\end{array}$ & $\begin{array}{l}\text { Eight teams; two } \\
\text { residents and } \\
\text { two RNs, each } \\
\text { Interprofessional }\end{array}$ & $\begin{array}{l}\mathrm{RCT}-\text { teams } \\
\text { randomized to } \\
\text { simulation- } \\
\text { based CRM or } \\
\text { didactic-based } \\
\text { CRM training. }\end{array}$ & $\begin{array}{l}\text { Obstetrical } \\
\text { emergency, } \\
\text { dystocia and } \\
\text { eclampsia }\end{array}$ & $\begin{array}{l}\text { Both groups } \\
\text { received } \\
\text { teaching on } \\
\text { CRM } \\
\text { principals. } \\
\text { Simulation } \\
\text { group received } \\
\text { three hours of } \\
\text { training in a } \\
\text { simulation } \\
\text { laboratory, the } \\
\text { didactic group } \\
\text { received three } \\
\text { hours of } \\
\text { lectures or } \\
\text { video and } \\
\text { hands-on } \\
\text { demonstration. }\end{array}$ & $\begin{array}{l}\text { Better team } \\
\text { performance } \\
\text { scores in } \\
\text { simulation } \\
\text { group ( } p= \\
0.01 \text { ), but no } \\
\text { difference in } \\
\text { MCQ scores } \\
\text { between both } \\
\text { groups. Both } \\
\text { measures were } \\
\text { unvalidated. } \\
\text { Kirkpatrick } 2 b\end{array}$ \\
\hline $\begin{array}{l}\text { Frengley et al., } \\
2011 \\
\text { New Zealand }\end{array}$ & $\begin{array}{l}40 \text { teams; one } \\
\text { critical care MDs } \\
\text { and four RNs, } \\
\text { each } \\
\text { Interprofessional }\end{array}$ & $\begin{array}{l}\text { Self-controlled } \\
\text { randomized } \\
\text { crossover } \\
\text { study - teams } \\
\text { randomized to } \\
\text { receive case- } \\
\text { based learning } \\
\text { on airway } \\
\text { scenario with } \\
\text { simulation- } \\
\text { based learning } \\
\text { on cardiac } \\
\text { scenario or } \\
\text { vice versa. } \\
\text { Simulation pre } \\
\text { and post-test } \\
\text { performance } \\
\text { were } \\
\text { compared. }\end{array}$ & $\begin{array}{l}\text { Acute/critical, } \\
\text { airway } \\
\text { emergency and } \\
\text { cardiac } \\
\text { arrhythmia }\end{array}$ & $\begin{array}{l}\text { Both groups } \\
\text { received skill } \\
\text { and teamwork } \\
\text { didactic } \\
\text { training prior } \\
\text { to simulation. } \\
\text { During the } \\
\text { simulation } \\
\text { intervention, } \\
\text { teamwork } \\
\text { behaviours } \\
\text { were } \\
\text { reinforced } \\
\text { during } \\
\text { simulation } \\
\text { debriefing. }\end{array}$ & $\begin{array}{l}\text { Significant } \\
\text { improvements } \\
\text { in scores for } \\
\text { overall } \\
\text { teamwork } \\
\text { ( } p<0.01 \text { ) using } \\
\text { the validated } \\
\text { TBR. Clinical } \\
\text { management } \\
\text { also improved } \\
\text { but no } \\
\text { significant } \\
\text { difference } \\
\text { between case- } \\
\text { or simulation- } \\
\text { based learning. } \\
\text { Kirkpatrick } 2 b\end{array}$ \\
\hline $\begin{array}{l}\text { Riley et al., } \\
2011 \\
\text { USA }\end{array}$ & $\begin{array}{l}134 \text { participants } \\
\text { (teams } \\
\text { allocation not } \\
\text { clear) of MDs, } \\
\text { RNs, CRNA, PA } \\
\text { Interprofessional }\end{array}$ & $\begin{array}{l}\text { RCT - three } \\
\text { hospitals } \\
\text { randomized to } \\
\text { simulation- } \\
\text { based, } \\
\text { didactic-based, } \\
\text { or no team } \\
\text { training. } \\
\text { Groups were }\end{array}$ & $\begin{array}{l}\text { Obstetrical } \\
\text { emergency; } \\
\text { uterine } \\
\text { rupture, } \\
\text { placental } \\
\text { abruption, and } \\
\text { post-partum } \\
\text { haemorrhage. }\end{array}$ & $\begin{array}{l}\text { Simulation } \\
\text { group received } \\
\text { in-situ } \\
\text { simulation } \\
\text { with two hour } \\
\text { debriefing } \\
\text { based on } \\
\text { TeamSTEPPS } \\
\text { Didactic group }\end{array}$ & $\begin{array}{l}\text { In situ } \\
\text { simulation } \\
\text { training } \\
\text { decreased } \\
\text { WAOS by } 37 \% \\
\text { compared to } \\
\text { pre - } \\
\text { intervention, } \\
\text { while other }\end{array}$ \\
\hline
\end{tabular}




\begin{tabular}{|c|c|c|c|c|c|}
\hline & & $\begin{array}{l}\text { compared } \\
\text { using adverse } \\
\text { outcome } \\
\text { scores. }\end{array}$ & & $\begin{array}{l}\text { had } \\
\text { TeamSTEPPS } \\
\text { only. }\end{array}$ & $\begin{array}{l}\text { groups did not. } \\
\text { No change in } \\
\text { COS attitudes } \\
\text { from pre to } \\
\text { post test. Both } \\
\text { measures were } \\
\text { validated } \\
\text { Kirkpatrick } 4\end{array}$ \\
\hline $\begin{array}{l}\text { Shapiro et al., } \\
2004 \\
\text { USA }\end{array}$ & $\begin{array}{l}\text { Four teams; one } \\
\text { MD, one } \\
\text { resident, three } \\
\text { RNs } \\
\text { Interprofessional }\end{array}$ & $\begin{array}{l}\text { RCT - teams } \\
\text { randomized to } \\
\text { simulation- } \\
\text { based or } \\
\text { didactic-based } \\
\text { team training. } \\
\text { Outcomes } \\
\text { during real } \\
\text { trauma } \\
\text { activations } \\
\text { were } \\
\text { compared. }\end{array}$ & $\begin{array}{l}\text { Acute/critical, } \\
\text { "three } \\
\text { scenarios of } \\
\text { increasing } \\
\text { complexity" }\end{array}$ & $\begin{array}{l}\text { Both teams } \\
\text { received } \\
\text { training on } \\
\text { "Emergency } \\
\text { Team } \\
\text { Coordination". } \\
\text { Simulation } \\
\text { group received } \\
\text { additional } \\
\text { eight hour } \\
\text { "intensive" } \\
\text { simulation } \\
\text { training with } \\
\text { debriefing. } \\
\text { Didactic group } \\
\text { worked in the } \\
\text { ED for one } \\
\text { eight hour shift } \\
\text { in their } \\
\text { respective } \\
\text { groups }\end{array}$ & $\begin{array}{l}\text { Simulation } \\
\text { group showed } \\
\text { a trend, but } \\
\text { was non- } \\
\text { significant } \\
\text { towards } \\
\text { improved team } \\
\text { behaviours ( } \mathrm{p}= \\
\text { 0.07) using the } \\
\text { validated TDRF } \\
\text { from BARS } \\
\text { during real } \\
\text { trauma } \\
\text { activations. } \\
\text { Kirkpatrick } 3\end{array}$ \\
\hline
\end{tabular}

Abbreviations: $\mathrm{RCT}$, randomized control study; $\mathrm{CRM}$, crisis resource management; $\mathrm{MD}$, medical doctor; RN, registered nurse; CRNA, certified registered nurse anaesthetist; PA, physician assistant; ED, Emergency department; $M C Q$, multiple choice quiz; TBR, teamwork behavioural rater; WAOS, weighted adverse outcomes score; COS, culture of safety; TDRF, team dimensions rating form; BARS, behavioural anchored rating scales. 
Table 3. Studies comparing the effect of simulation-based crisis resource management team training versus simulation without crisis resource management training

\begin{tabular}{|c|c|c|c|c|c|}
\hline Source & Participants & Study design & $\begin{array}{l}\text { Context of } \\
\text { the crisis }\end{array}$ & $\begin{array}{l}\text { Learning } \\
\text { intervention }\end{array}$ & $\begin{array}{l}\text { Outcomes, } \\
\text { Kirkpatrick level }\end{array}$ \\
\hline $\begin{array}{l}\text { UK SaFE } \\
\text { Study } \\
\text { Crofts et } \\
\text { al., } 2007\end{array}$ & $\begin{array}{l}24 \text { teams; 5-6 } \\
\text { members each } \\
\text { of 1-2 MDs } \\
\text { (junior or senior) } \\
\text { and 3-4 } \\
\text { midwives (junior } \\
\text { or senior) } \\
\text { Interprofessional }\end{array}$ & $\begin{array}{l}\text { RCT }-2 \times 2 \\
\text { factorial } \\
\text { design where } \\
\text { teams were } \\
\text { randomized } \\
\text { to training in } \\
\text { local } \\
\text { hospitals or } \\
\text { at a } \\
\text { simulation } \\
\text { centre, and } \\
\text { to teamwork } \\
\text { theory or not }\end{array}$ & $\begin{array}{l}\text { Obstetrical } \\
\text { emergencies, } \\
\text { eclampsia, } \\
\text { postpartum } \\
\text { haemorrhage, } \\
\text { and shoulder } \\
\text { dystocia (J. } \\
\text { Phillips, 1995) }\end{array}$ & $\begin{array}{l}\text { All training } \\
\text { courses } \\
\text { included a } \\
\text { lecture and } \\
\text { simulation drill } \\
\text { (with feedback). } \\
\text { Groups in local } \\
\text { hospitals used } \\
\text { low-fidelity } \\
\text { simulation with } \\
\text { patient-actors, } \\
\text { while the } \\
\text { simulation }\end{array}$ & $\begin{array}{l}\text { Mean validated } \\
\text { MCQ scores } \\
\text { increased from } \\
\text { pre to post test } \\
(p<0.01) \text { but no } \\
\text { effect on } \\
\text { location of } \\
\text { training or the } \\
\text { inclusion of } \\
\text { team theory. } \\
\text { Kirkpatrick } 2 b \\
\text { Training with }\end{array}$ \\
\hline $\begin{array}{l}\text { Crofts et } \\
\text { al., } 2008\end{array}$ & & 8 & & $\begin{array}{l}\text { centre used a } \\
\text { high-fidelity } \\
\text { mannequin. } \\
\text { Teams } \\
\text { randomized to } \\
\text { teamwork } \\
\text { theory received } \\
\text { additional } \\
\text { instruction on } \\
\text { communication } \\
\text { and } \\
\text { coordination } \\
\text { during crisis. }\end{array}$ & $\begin{array}{l}\text { patient-actors } \\
\text { improved } \\
\text { perception of } \\
\text { safety ( } p=0.05) \\
\text { and } \\
\text { communication } \\
(p=0.35) \text { but } \\
\text { not with high- } \\
\text { fidelity } \\
\text { mannequin } \\
\text { training. } \\
\text { Teamwork } \\
\text { training did not } \\
\text { offer additional } \\
\text { benefit. } \\
\text { Kirkpatrick } 2 b\end{array}$ \\
\hline $\begin{array}{l}\text { Ellis et al., } \\
2010\end{array}$ & & & & & $\begin{array}{l}\text { Validated GRS } \\
\text { improved from } \\
\text { pre to post in all } \\
\text { groups }(p<0.01) \text {, } \\
\text { no additional } \\
\text { benefit seen } \\
\text { with location of } \\
\text { training or } \\
\text { additional } \\
\text { teamwork } \\
\text { training. } \\
\text { Kirkpatrick } 2 b\end{array}$ \\
\hline $\begin{array}{l}\text { Siassakos } \\
\text { et al., } 2009 \\
\text { UK }\end{array}$ & $\begin{array}{l}\text { four teams; one } \\
\text { senior and two } \\
\text { junior MDs, and }\end{array}$ & $\begin{array}{l}\text { RCT - Subset } \\
\text { of the teams } \\
\text { who were }\end{array}$ & & & $\begin{array}{l}\text { Quantitative } \\
\text { content analysis } \\
\text { showed that } \\
\text { CRM trained }\end{array}$ \\
\hline
\end{tabular}




\begin{tabular}{|c|c|c|c|c|c|}
\hline & $\begin{array}{l}\text { two junior } \\
\text { midwives } \\
\text { Interprofessional }\end{array}$ & $\begin{array}{l}\text { randomized } \\
\text { to simulation } \\
\text { training with } \\
\text { or without } \\
\text { CMR training. }\end{array}$ & & & $\begin{array}{l}\text { groups had less } \\
\text { "clutter" and } \\
\text { fewer } \\
\text { undirected } \\
\text { commands. } \\
\text { Kirkpatrick 2b }\end{array}$ \\
\hline $\begin{array}{l}\text { Jankouskas } \\
\text { et al., } 2011 \\
\text { USA }\end{array}$ & $\begin{array}{l}24 \text { teams; two } \\
\text { med students } \\
\text { and two nursing } \\
\text { students, each } \\
\text { Interprofessional }\end{array}$ & $\begin{array}{l}\text { RCT - } \\
\text { randomizing } \\
\text { BLS with or } \\
\text { without } \\
\text { additional } \\
\text { CRM training. } \\
\text { Team } \\
\text { behaviours. } \\
\text { Pre and post- } \\
\text { test } \\
\text { simulation } \\
\text { behaviours } \\
\text { were } \\
\text { compared. }\end{array}$ & $\begin{array}{l}\text { Acute/critical, } \\
\text { basic life } \\
\text { support in } \\
\text { two } \\
\text { hypoxemic } \\
\text { arrests in a } \\
\text { hospital } \\
\text { setting }\end{array}$ & $\begin{array}{l}\text { For the } \\
\text { experimental } \\
\text { group, } \\
\text { debriefing of } \\
\text { the pre-test } \\
\text { sims focused on } \\
\text { team processes } \\
\text { and didactic } \\
\text { content } \\
\text { included CRM } \\
\text { with BLS } \\
\text { review. For } \\
\text { teams in the } \\
\text { control group, } \\
\text { debriefing was } \\
\text { on clinical skills } \\
\text { and the didactic } \\
\text { content } \\
\text { included BLS } \\
\text { only. }\end{array}$ & $\begin{array}{l}\text { CRM } \\
\text { significantly } \\
\text { improved the } \\
\text { team process } \\
\text { variables of } \\
\text { team working, } \\
\text { task } \\
\text { management, } \\
\text { and situation } \\
\text { awareness in the } \\
\text { validated ANTS } \\
\text { tool (p < 0.05). } \\
\text { No difference on } \\
\text { team } \\
\text { effectiveness } \\
\text { (unvalidated) } \\
\text { variables or } \\
\text { interprofessiona } \\
\text { attitudes. } \\
\text { Kirkpatrick } 2 b \text {. }\end{array}$ \\
\hline $\begin{array}{l}\text { Thomas et } \\
\text { al., } 2007 \\
\text { USA }\end{array}$ & $\begin{array}{l}\text { Teams of two to } \\
\text { three residents } \\
\text { each }(\mathrm{N}=40) \\
\text { Interdisciplinary }\end{array}$ & $\begin{array}{l}\text { RCT - teams } \\
\text { randomized } \\
\text { to low- } \\
\text { fidelity NPR } \\
\text { training with } \\
\text { or without } \\
\text { additional } \\
\text { team } \\
\text { training. Post } \\
\text { intervention } \\
\text { mega code } \\
\text { outcomes } \\
\text { were } \\
\text { compared. }\end{array}$ & $\begin{array}{l}\text { Neonatal } \\
\text { resuscitation, } \\
\text { not specified }\end{array}$ & $\begin{array}{l}\text { Both arms were } \\
\text { exposed to low } \\
\text { fidelity baby } \\
\text { models during } \\
\text { the standard } \\
\text { NRP teaching. } \\
\text { Teamwork } \\
\text { group had } \\
\text { additional two } \\
\text { hour training } \\
\text { including } \\
\text { lectures, more } \\
\text { low-fidelity role } \\
\text { playing, video } \\
\text { clips and a } \\
\text { questions and } \\
\text { answer period. }\end{array}$ & $\begin{array}{l}\text { Compared with } \\
\text { the standard } \\
\text { NRP, NRP with a } \\
\text { teamwork and } \\
\text { human error } \\
\text { curriculum led } \\
\text { interns to } \\
\text { exhibit more } \\
\text { team behaviours } \\
\text { (p<0.01), } \\
\text { vigilance and } \\
\text { workload } \\
\text { management } \\
\text { (unvalidated } \\
\text { tools an no p- } \\
\text { value reported) } \\
\text { during simulated } \\
\text { resuscitations. } \\
\text { Kirkpatrick } 2 b\end{array}$ \\
\hline $\begin{array}{l}\text { Thomas et } \\
\text { al., } 2010 \\
\text { USA }\end{array}$ & $\begin{array}{l}\text { Teams three to } \\
\text { four residents } \\
\text { each }(\mathrm{N}=100) \\
\text { Interdisciplinary }\end{array}$ & $\begin{array}{l}\text { RCT - teams } \\
\text { randomized } \\
\text { to either LFT } \\
\text { NRP } \\
\text { teaching, LFT } \\
\text { NRP teaching } \\
\text { with team }\end{array}$ & $\begin{array}{l}\text { Neonatal } \\
\text { resuscitation, } \\
\text { precipitous } \\
\text { delivery, two } \\
\text { hypovolemia } \\
\text { scenarios }\end{array}$ & $\begin{array}{l}\text { Additional team } \\
\text { training was } \\
\text { similar to } \\
\text { above.(Thomas } \\
\text { et al., 2007) }\end{array}$ & $\begin{array}{l}\text { Interns whose } \\
\text { NRP course } \\
\text { included a brief } \\
\text { teamwork } \\
\text { curriculum used } \\
\text { more frequent } \\
\text { teamwork }\end{array}$ \\
\hline
\end{tabular}




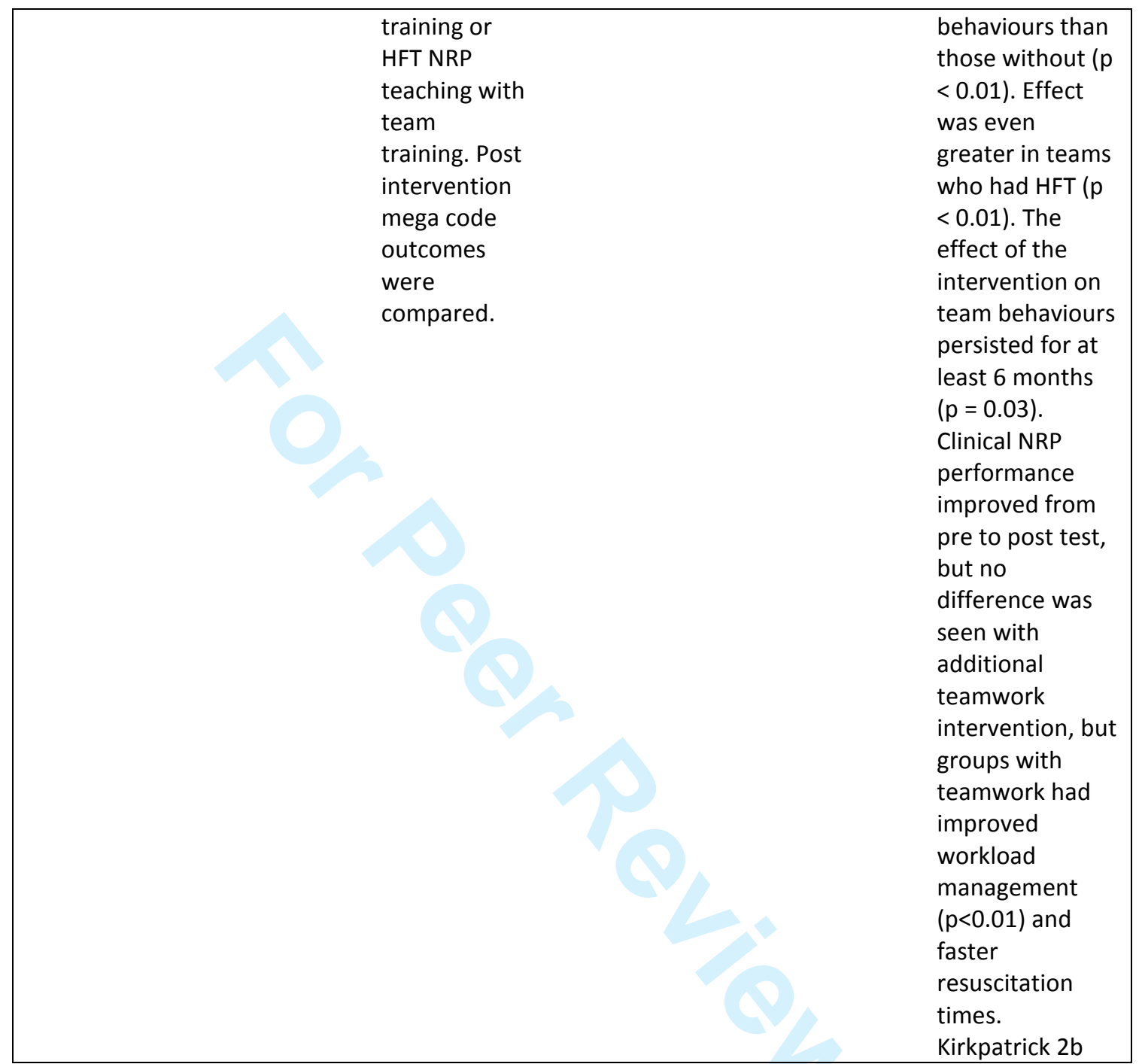

Abbreviations: SaFE, Simulation and Fire-drill Evaluation; LFT, low-fidelity training; HFT, high fidelity training; NRP, neonatal resuscitation program; GRS (global rating scale); ANTS, anaesthetists' non-technical skills; GRS, global rating scale; BLS, basic life support; 
Table 4. Studies comparing a specific simulation-based teaching methods or learning outcomes assessed using an interrupted time series study design

\begin{tabular}{|c|c|c|c|c|c|}
\hline Source & Participants & Study design & $\begin{array}{l}\text { Context of the } \\
\text { crisis }\end{array}$ & $\begin{array}{l}\text { Learning } \\
\text { intervention, } \\
\text { comparator } \\
\text { group }\end{array}$ & $\begin{array}{l}\text { Outcomes, } \\
\text { Kirkpatrick level }\end{array}$ \\
\hline $\begin{array}{l}\text { Boet et al., } \\
2013 \\
\text { Canada }\end{array}$ & $\begin{array}{l}40 \text { teams; one } \\
\text { anaesthesia } \\
\text { resident, surgery } \\
\text { resident, RN } \\
\text { each. } \\
\text { Interprofessional }\end{array}$ & $\begin{array}{l}\text { RCT - teams } \\
\text { randomized to } \\
\text { receive "team } \\
\text { debriefing" or } \\
\text { "expert lead" } \\
\text { debriefing. Pre } \\
\text { and post team } \\
\text { behaviours in } \\
\text { the simulator } \\
\text { were compared. }\end{array}$ & $\begin{array}{l}\text { Acute/critical } \\
\text { care, } \\
\text { intraoperative } \\
\text { emergencies } \\
\text { with cardiac } \\
\text { arrhythmias }\end{array}$ & $\begin{array}{l}\text { Both groups } \\
\text { received didactic } \\
\text { CRM teaching } \\
\text { prior to any } \\
\text { simulation. } \\
\text { Debriefing in } \\
\text { both groups was } \\
\text { modelled after } \\
\text { the Ottawa GRS } \\
\text { with video } \\
\text { playback. "Team } \\
\text { debriefing " } \\
\text { group did not } \\
\text { have an expert } \\
\text { facilitator, while } \\
\text { the "expert lead" } \\
\text { group did. }\end{array}$ & $\begin{array}{l}\text { Validated TEAM } \\
\text { scale scores } \\
\text { significantly } \\
\text { improved from pre } \\
\text { to post-test }(p= \\
0.01 \text { ) regardless of } \\
\text { the style of } \\
\text { debriefing. } \\
\text { Kirkpatrick } 2 b\end{array}$ \\
\hline $\begin{array}{l}\text { LeFlore et } \\
\text { al., } 2009 \\
\text { USA }\end{array}$ & $\begin{array}{l}13 \text { teams of } \\
\text { health care } \\
\text { students; one } \\
\text { NP, RN, SW and } \\
\text { RT student in } \\
\text { each team. } \\
\text { Interprofessional }\end{array}$ & $\begin{array}{l}\text { RCT - teams } \\
\text { randomized to } \\
\text { self-directed } \\
\text { learning with } \\
\text { facilitated } \\
\text { debriefing } \\
\text { versus } \\
\text { instructor- } \\
\text { modelled } \\
\text { learning with } \\
\text { modified } \\
\text { debriefing. }\end{array}$ & $\begin{array}{l}\text { Neonatal } \\
\text { resuscitation }\end{array}$ & $\begin{array}{l}\text { Group A had a } \\
\text { simulation pre } \\
\text { test followed by } \\
\text { facilitated } \\
\text { debriefing in } \\
\text { clinical and } \\
\text { communication } \\
\text { and coordination } \\
\text { abilities, while } \\
\text { group B observe } \\
\text { an instructor } \\
\text { modelled } \\
\text { learning } \\
\text { simulation } \\
\text { scenario and } \\
\text { modified } \\
\text { debriefing. Both } \\
\text { teams then } \\
\text { underwent a } \\
\text { post-test } \\
\text { simulation } \\
\text { scenario. }\end{array}$ & $\begin{array}{l}\text { No difference in } \\
\text { unvalidated } \\
\text { knowledge tests } \\
\text { when pre- vs. } \\
\text { post-test were } \\
\text { compared ( } p>0.4 \text { ), } \\
\text { Eight out of } 11 \\
\text { items on the TET } \\
\text { were completed } \\
\text { faster ( } p<0.05 \text { ) } \\
\text { and } 8 \text { out of } 10 \\
\text { item on the BAT } \\
\text { were greater } \\
\text { ( } p<0.04 \text { ) in the } \\
\text { expert modelled } \\
\text { group compared } \\
\text { to the self- } \\
\text { directed group. } \\
\text { Kirkpatrick } 2 a, b\end{array}$ \\
\hline $\begin{array}{l}\text { Miller et } \\
\text { al., } 2012 \\
\text { USA }\end{array}$ & $\begin{array}{l}39 \text { trauma } \\
\text { activations } \\
\text { involving staff } \\
\text { MDs and } \\
\text { residents, RNs, } \\
\text { technicians, }\end{array}$ & $\begin{array}{l}\text { ITS - teamwork } \\
\text { behaviours were } \\
\text { observed during } \\
\text { real trauma } \\
\text { activations and } \\
\text { compared over }\end{array}$ & $\begin{array}{l}\text { Acute/critical } \\
\text { care, } \\
\text { hypovolemic } \\
\text { shock from } \\
\text { blunt } \\
\text { abdominal }\end{array}$ & $\begin{array}{l}\text { Didactic phase } \\
\text { included } \\
\text { standardized } \\
\text { lectures on team } \\
\text { member role } \\
\text { clarification. ISTS }\end{array}$ & $\begin{array}{l}\text { Validated CTS } \\
\text { measures for } \\
\text { teamwork } \\
\text { improved in } 12 \\
\text { out of } 14 \text { domains } \\
\text { during ISTS phase }\end{array}$ \\
\hline
\end{tabular}




\begin{tabular}{|c|c|c|c|c|c|}
\hline & $\begin{array}{l}\text { pharmacists, } \\
\text { clerks, and RTs } \\
\text { in an ED. } \\
\text { Interprofessional }\end{array}$ & $\begin{array}{l}\text { four periods: pre } \\
\text { test (baseline, } \\
\text { didactic-based } \\
\text { phase) and post } \\
\text { test (simulation } \\
\text { and decay } \\
\text { phase) }\end{array}$ & $\begin{array}{l}\text { trauma and } \\
\text { penetrating } \\
\text { chest injury. }\end{array}$ & $\begin{array}{l}\text { phase (eight } \\
\text { weeks) included } \\
\text { simulation } \\
\text { highlighting } \\
\text { teamwork and } \\
\text { communication. } \\
\text { Decay phase was } \\
\text { one week } \\
\text { following the } \\
\text { end of ISTS } \\
\text { phase. }\end{array}$ & $\begin{array}{l}\text { compared to } \\
\text { baseline, whereas } \\
\text { only } 1 \text { CTS } \\
\text { improved during } \\
\text { the didactic phase. } \\
\text { All CTS measures } \\
\text { returned to } \\
\text { baseline during } \\
\text { the decay phase. } \\
\text { Kirkpatrick } 4\end{array}$ \\
\hline $\begin{array}{l}\text { Phipps et } \\
\text { la., } \\
2012 \\
\text { USA }\end{array}$ & $\begin{array}{l}\text { 185 team } \\
\text { members (MDs, } \\
\text { RNs, midwives, } \\
\text { CRNA) were } \\
\text { exposed to the } \\
\text { intervention. } \\
\text { Interprofessional }\end{array}$ & $\begin{array}{l}\text { ITS - hospital } \\
\text { wide, } \\
\text { interprofessional } \\
\text { simulation - } \\
\text { based CRM } \\
\text { intervention was } \\
\text { applied to assess } \\
\text { attitudes on } \\
\text { COS, patient } \\
\text { satisfaction and } \\
\text { AOI data } \\
\text { collected eight } \\
\text { quarters pre- } \\
\text { interruption and } \\
\text { six quarters post } \\
\text { interruption. }\end{array}$ & $\begin{array}{l}\text { Obstetrical } \\
\text { emergency, } \\
\text { scenarios not } \\
\text { described. }\end{array}$ & $\begin{array}{l}\text { CRM was taught } \\
\text { using a didactic } \\
\text { portion ( } 4 \text { hours) } \\
\text { followed by a } \\
\text { four hour } \\
\text { simulation days } \\
\text { three to seven } \\
\text { days later which } \\
\text { incorporated } \\
\text { more CRM into } \\
\text { the video- } \\
\text { assisted, expert- } \\
\text { lead debriefing. }\end{array}$ & $\begin{array}{l}\text { AOls significantly } \\
\text { decreased from } \\
0.05 \text { ( } 95 \% \mathrm{Cl} 0.05- \\
0.05) \text { at baseline } \\
\text { to } 0.04(95 \% \mathrm{Cl} \text {, } \\
0.04-0.05) \text {. } \\
\text { Staff's attitudes } \\
\text { towards patient } \\
\text { safety improved } \\
\text { and patient } \\
\text { satisfaction was } \\
\text { maintained. } \\
\text { Kirkpatrick } 4\end{array}$ \\
\hline
\end{tabular}

Abbreviations: MD, medical doctor; NP, nurse practitioner; RN, registered nurse; CRNA, certified registered nurse anaesthetist; SW, social work; $\mathrm{RT}$, respiratory therapy; OR, operation room; ED, emergency department; RCT, randomized control trial; ITS, interrupted time series; TEAM, team emergency assessment measure; TET, technical evaluation tool; BAT, behavioural assessment tool; ISTS, in-situ trauma simulation; CTS, clinical teamwork scale; $\mathrm{COS}$, culture of safety; $\mathrm{AOI}$, adverse outcome index 
Appendix: Risk of bias summary ${ }^{a, b}$

5

6

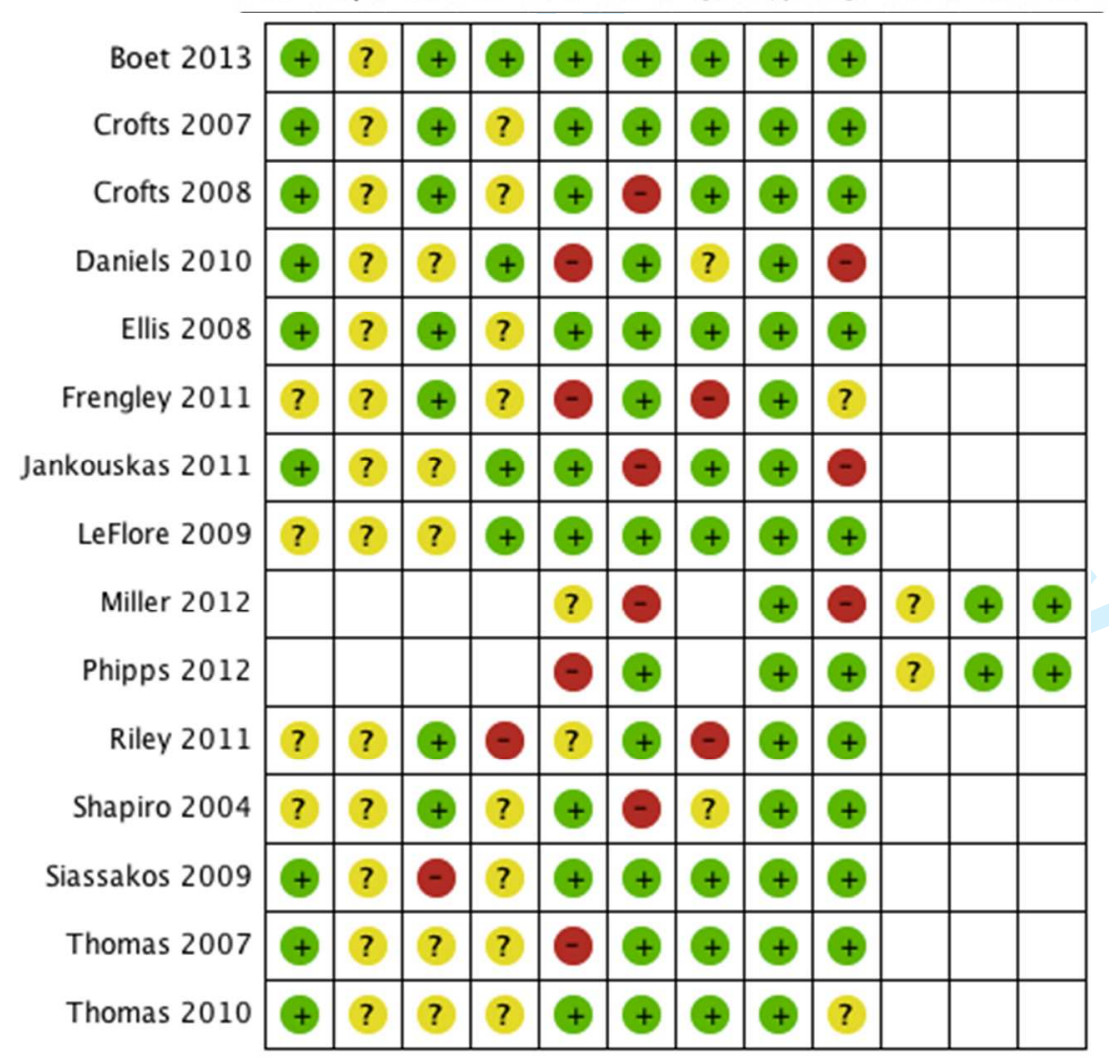

Green $=$ low risk, yellow $=$ intermediate risk or unclear, red $=$ high risk.

${ }^{\text {a }}$ A Review of author's judgments about each risk of bias for each included study is available at request.

${ }^{b}$ Other biases noted included self-selection bias among volunteer participants,(Daniels et al., 2010; Jankouskas, Haidet, Hupcey, Kolanowski, \& Murray, 2011) responder bias,(Frengley et al., 2011) selection bias,(Thomas et al., 2010) and sampling bias.(Miller, Crandall, Washington, \& McLaughlin, 2012) 